\title{
Introduction to \\ Control Theory
}


Also from The Macmillan Education

Introduction to State-variable Analysis

P. F. Blackman

Control Engineering, Theory, worked examples and problems

R. V. Buckley

Fluid Power Systems, Theory, worked examples and problems

A. B. Goodwin

Hydraulic Systems Anaysis

J. D. Stringer 


\title{
Introduction to Control Theory
}

\author{
S. A. MARSHALL
}

Chairman and Professor of Mechanical Engineering,

University of Wollongong,

New South Wales

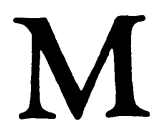


All rights reserved. No part of this publication may be reproduced or transmitted, in any form or by any means, without permission.

\author{
First published 1978 by \\ THE MACMILLAN PRESS LTD \\ London and Basingstoke \\ Associated companies in Delhi Dublin \\ Hong Kong Johannesburg Lagos Melbourne \\ New York Singapore and Tokyo \\ Typeset in 10/11 IBM Press New Roman by \\ Reproduction Drawings Ltd, Sutton, Surrey
}

\begin{tabular}{l}
\hline British Library Cataloguing in Publication Data \\
\hline Marshall, S. A. \\
Introduction to control theory \\
1. Control theory \\
I. Title \\
$629.8^{\prime} 312 \quad$ QA402.3 \\
ISBN 978-0-333-18312-0 ISBN 978-1-349-15910-9 (eBook) \\
DOI 10.1007/978-1-349-15910-9 \\
\hline
\end{tabular}

This book is sold subject to the standard conditions of the Net Book Agreement.

The paperback edition of this book is sold subject to the condition that it shall not, by way of trade or otherwise, be lent, resold, hired out, or otherwise circulated without the publisher's prior consent in any form of binding or cover other than that in which it is published and without a similar condition including this condition being imposed on the subsequent purchaser. 
To my wife, Margaret Rose 


\section{Contents}

Preface $\quad$ xi

1 Introduction 1

1.1 Open- and Closed-loop Concepts 1

1.2 Historical Development 2

1.3 Outline of Text 2

2 Mathematical Modelling 4

2.1 The Need for Mathematical Modelling 4

2.2 Description of Simple Mechanical Systems 5

2.3 More about Mathematical Modelling 9

2.4 Model of a Trailer Suspension System 9

$\begin{array}{ll}2.5 & \text { Modelling of Simple Electrical Systems } \\ 2.6\end{array}$

2.6 Modelling of Chemical Systems 16

2.7 Linearisation of Non-linear Equations 18

2.8 Concluding Remarks 20

3 The Need for Some Mathematics 23

3.1 Classical Method of Solution of Linear Differential Equations 24

3.2 Introduction to the Laplace Transformation 27

3.3 Some Properties of the Laplace Transformation 28

3.4 Laplace Transformations of Some Time Functions 30

3.5 Roots of Polynomials 32

3.6 Partial-fraction Expansions 35

3.7 Solution of Linear Differential Equations Using the Laplace
Transformation

3.8 Second-order Differential Equations 41 
4.1 Open-loop and Closed-loop Control 49

4.2 Transfer Functions $\quad 53$

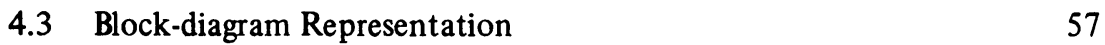

$\begin{array}{lll}4.4 & \text { Signal-flow Graphs } & 64\end{array}$

4.5 Concluding Remarks 69

$5 \quad$ Steady-state and Transient Behaviour of Control Systems 73

$\begin{array}{lll}5.1 & \text { Performance Criteria } & 73\end{array}$

5.2 Absolute Stability: the Method of Routh 75

$\begin{array}{ll}\text { 5.3 Steady-state Analysis and Classification of Systems } & 79\end{array}$

$\begin{array}{lll}5.4 & \text { Transient Behaviour of Control Systems } & 87\end{array}$

$\begin{array}{ll}\text { 5.5 Sensitivity of Control Systems } & 96\end{array}$

$\begin{array}{lr}\text { 5.6 Behaviour of a Governor System } & 98\end{array}$

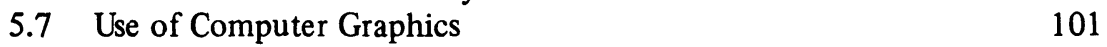

6 The Root-locus Method 105

$\begin{array}{llr}6.1 & \text { Pole-Zero Configuration } & 106\end{array}$

$\begin{array}{ll}\text { 6.2 Root-locus Method } & 109\end{array}$

6.3 Rules for Drawing the Root-locus Diagram 111

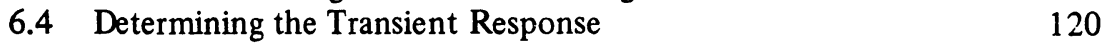

6.5 Use of Digital Computer and Graphics Terminal 124

7 Frequency-response Methods 129

$\begin{array}{ll}\text { 7.1 Derivation of the Frequency Response of a System } & 130\end{array}$

7.2 Graphical Representation of the Frequency-response Function 136

$\begin{array}{lll}7.3 & \text { Stability from the Nyquist Diagram } & 154\end{array}$

7.4 Relative Stability: Gain and Phase Margins 161

7.5 Closed-loop Performance from Open-loop Frequency Characteristics 163

$\begin{array}{lll}7.6 & \text { Performance Requirements } & 171\end{array}$

$\begin{array}{lll}7.7 & \text { System Sensitivity } & 172\end{array}$

$\begin{array}{ll}7.8 & 172\end{array}$

8 Control-system Synthesis 175

$\begin{array}{lll}\text { 8.1 Series Compensation } & 177\end{array}$

$\begin{array}{ll}\text { 8.2 Parallel Compensation } & 184\end{array}$

8.3 System Synthesis in the $s$-plane Using the Root-locus Method 186

8.4 System Synthesis in the $G(\mathrm{j} \omega) H(\mathrm{j} \omega)$ Plane Using the Frequencyresponse Method

8.5 System Synthesis in the $G(\mathrm{j} \omega) H(\mathrm{j} \omega)$ Plane Using the Nyquist Diagram

8.6 System Synthesis in the $G(\mathrm{j} \omega) H(\mathrm{j} \omega)$ Plane Using the Inverse $\begin{array}{ll}\text { Nyquist Diagram } & 203\end{array}$

$\begin{array}{lll}8.7 & \text { Feedforward Control } & 205\end{array}$

$\begin{array}{ll}8.8 \text { Concluding Remarks } & 207\end{array}$ 
9 Bridging the Gap 210

9.1 Representation of Multivariable Systems 212

9.2 The Inverse-Nyquist-array Technique 216

9.3 Conclusion 224

$\begin{array}{ll}\text { Appendix } & 226\end{array}$

$\begin{array}{ll}\text { Index } & 229\end{array}$ 


\section{Preface}

This book has arisen, after many years' association with automatic control both in the university and in industry, from the growing conviction that there is a need for a new and modern text dealing with classical linear control theory, especially since many universities and polytechnics now have access to digital computers that have graphics terminals for interactive design work. Most of the classical control work is concerned with the analysis of the behaviour of closed-loop systems using knowledge of the open-loop system together with well-tried graphical techniques. It is this dependence that creates new possibilities for the use of control theory-there is now no need for laborious hand calculation and graph plotting since it is possible to automate all the techniques and carry out the analysis and synthesis of control systems via a graphics terminal with accuracy and speed. Further, it is possible to interact with the computing system and hence to build up progressive design techniques.

It has been recognised for some years that classical control theory has not been sufficiently developed to include techniques for designing industrial control systems in which there are many inputs and outputs and interaction between the control loops; hence alternative methods have been developed. Recent developments (at U.M.I.S.T.) have shown that the design of such control systems may be tackled in two parts: firstly, the interaction is systematically reduced until it can be safely ignored; and secondly, the many control loops may subsequently be designed using classical control theory. These developments in control theory stress the need for a thorough understanding of the classical approach. Indeed, in his book Computer-Aided Control System Design, Professor H. H. Rosenbrock states that 'The second development which will have a profound and increasing influence on all engineering design, is the availability of computers with graphical display. This allows a complete re-evaluation of the existing frequency-response methods, so that the graphical features are used only for communication with the designer, and not to replace standard numerical procedures for root solving etc....'

This book was written mainly during my leisure hours and consequently was made possible only by the continued encouragement and understanding of my wife. 